\title{
IMPLEMENTASI KEBIJAKAN VAKSINASI COVID-19 DI KOTA BOYOLALI
}

\section{Niken, Putri Mia, Septiana, Reyhan, Argha, Putra}

Universitas Diponegoro (UNDIP) Semarang Jawa Tengah, Indonesia

Email: nnikenputri390@gmail.com, augustinrina@lecturer.undip.ac.id kismartini@live.undip.ac.id, rey24rap@gmail.com

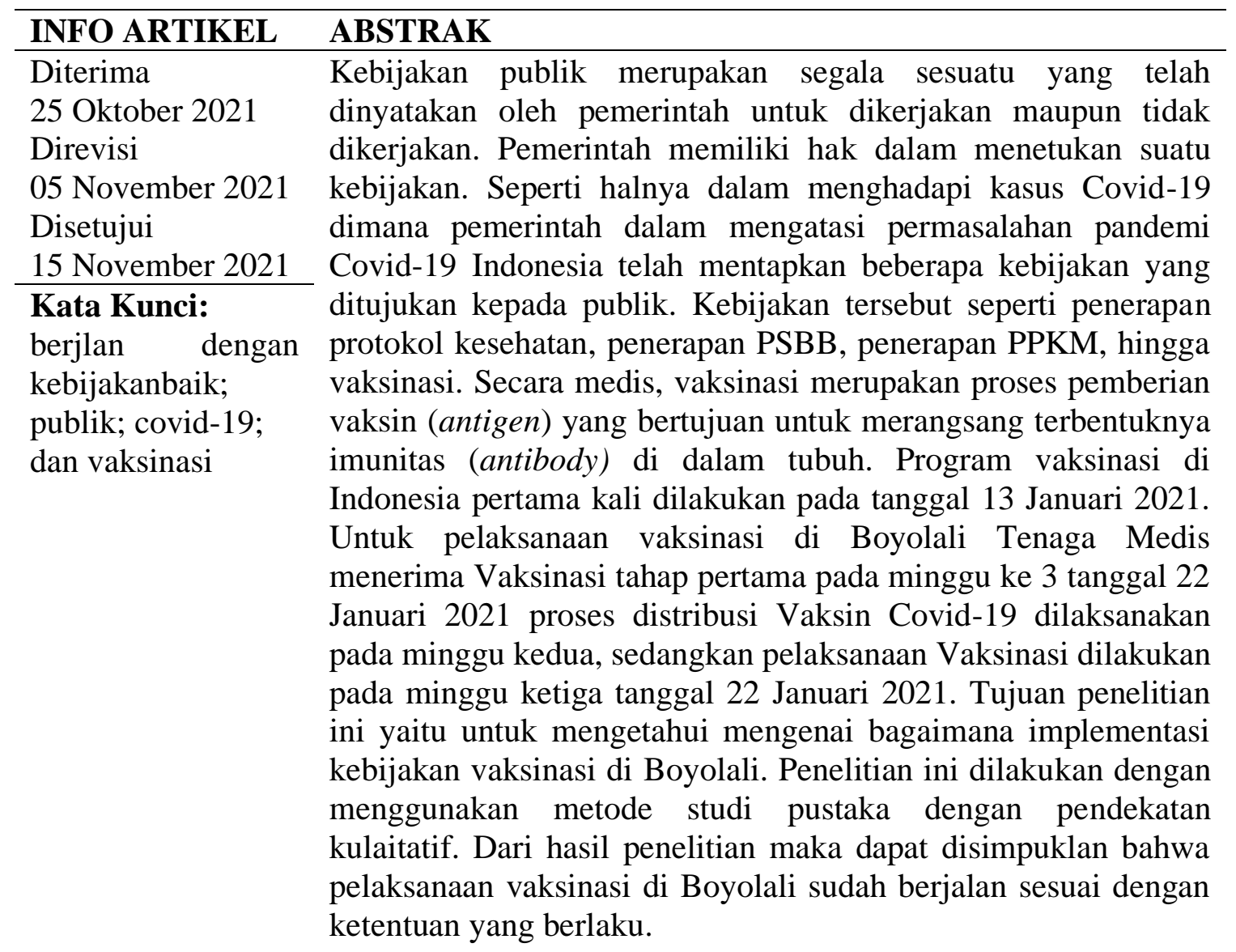

\section{ABSTRACT}

Public policy is everything that has been stated by the government to be done or not done. The government has the right to determine a policy. As is the case in dealing with the Covid-19 case where the government in overcoming the problems of the Indonesian Covid-19 pandemic has established several policies aimed at the public. These policies include the implementation of health protocols, the implementation of PSBB, the implementation of PPKM, to vaccinations. Medically, vaccination is the process of administering a vaccine (antigen) which aims to stimulate the formation of immunity (antibody) in the body. The vaccination program in Indonesia was first carried out on January 13, 2021. For the implementation of

$\begin{array}{ll}\text { How to cite: } & \text { Niken, N., Putri Mia, Septiana, Reyhan, Argha, Putra. (2021) Implementasi Kebijakan Vaksinasi Covid- } \\ & 19 \text { di Kota Boyolali. Jurnal Syntax Admiration 2(11). https://doi.org/10.46799/jsa.v2i11.343 } \\ \text { E-ISSN: } & 2722-5356 \\ \text { Published by: } & \text { Ridwan Institute }\end{array}$


vaccinations in Boyolali, medical personnel received the first stage of vaccination on the 3rd week of January 22, 2021, the distribution process for the Covid-19 vaccine was carried out in the second week, while the vaccination was carried out in the third week. January 22, 2021. The purpose of this study is to find out how the implementation of vaccination policy in Boyolali. This research was conducted using a literature study method Keywords: public with a qualitative approach. From the results of the study, it can policy, covid-19, be concluded that the implementation of vaccination in Boyolali vaccinations

has been running in accordance with applicable regulations

\section{Pendahuluan}

Pada akhir tahun 2019, dunia termasuk Indonesia telah dihebohkan dengan sebuah virus baru yang membuat semua warganya menjadi resah akibat adanya virus corona (Covid-19). Hingga pada tanggal 12 Maret 2021 WHO (Word Health Organization) mengumumkan jika Covid-19 ini dinyatakan sebagai pandemi karena jumlah kasusnya yang semakin hari semakin naik, dan juga wabah ini telah dinyatakan sebagai darurat kesehatan global (Putri et al., 2020). Wabah ini telah memakan banyak korban, bahkan terhitung pada bulan Agustus 2021 sebanyak 200 juta kasus di dunia dan diantaranya 4,2 juta kasus kematian. Di Indonesia, pada bulan Juni kasus Covid-19 telah mencapai 1,9 juta kasus dan kasus kematian sebesar 52 ribu. Sedangkan pada bulan Agustus 2021 mencapai 3,6 juta kasus dan terdapat 104 ribu kasus kematian. Lonjakan kasus tersebut diakibatkan oleh adanya varian baru virus corona yang memiliki tingkat penularan lebih tinggi. Dalam mengatasi kasus ini, pemerintah telah mengupayakan dengan menerapkan beberapa kebijakan seperti penerapan protokol kesehatan, penerapan PPKM hingga berjilid-jilid, kebijakan vaksinasi, dan lain-lain. Vaksin COVID-19 dikembangkan untuk membantu pembentukan imunitas tubuh individu sehingga pemberian vaksin COVID-19 tersebut diharapkan dapat mempercepat terbentuknya kekebalan kelompok (herd immunity) yang nantinya berdampak pada penurunan jumlah kasus yang terinfeksi (Organization, 2020). Selama bertahun-tahun vaksin terbukti dapat menurunkan kejadian penyakit menular melalui mekanisme imunitas tubuh manusia (Stuppia et al., 2011).

Program vaksinasi di Indonesia pertama kali dilakukan pada tanggal 13 Januari 2021 yang suntikan pertamanya diberikan kepada presiden Joko Widodo. Vaksinasi ini dilakukan dalam beberapa gelombang, yaitu gelombang pertama diberikan kepada tenaga kesehatan, petugas publik, dan lansia. Untuk gelombang kedua diberikan kepada masyarakat rentan dan masyarakat umum (Kemenkes RI, 2021a). Jenis vaksin yang telah dan akan digunakan di Indonesia adalah AstraZeneca, Moderna, Pfizer, Sinopharm dan Sinovac (RI, 2019). Semua jenis vaksin tersebut memiliki efektivitas yang berbeda berdasarkan uji klinisnya. WHO memaparkan bahwa kinerja vaksin dapat dilihat dari tiga pengukuran yaitu melalui efikasi, efektivitas, dan dampak vaksin (Organization, 2020). 
Dengan adanya program vaksinasi, menimbulkan pro dan kontra di masyarakat Berdasarkan survei yang dilakukan oleh kementrian Kesehatan RI, ITAGI, UNICEF dan WHO secara daring pada 19-30 September 2020 dengan $76 \%$ responden berusia 18-45 tahun, diketahui bahwa terdapat kekhawatiran yang cukup besar mengenai efektivitas dan keamanan dari vaksin, rasa kurang percaya terhadap vaksin, dan permasalahan mengenai halal tidaknya vaksin. Dengan adanya permasalahanpermasalahan tersebut maka perlu adanya pengkajian mengenai implementasi kebijakan vaksinasi covid-19, khususnya adalah di kota Boyolali.

Untuk menghindari anggapan kesamaan dengan penelitian ini, maka kajian pustaka mencantumkan penelitian terdahulu sebagai berikut: Hasil Penelitian Aviandari (Tifa, 2021). Penelitian ini berjudul Analisis Manajemen Implementasi Vaksinasi Covid-19 Dalam Menurunkan Angka Positif di Dinas Kesehatan Kabupaten Boyolali, Jawa Tengah. Penelitian ini menggunakan metode penelitian kualitatif dengan pendekatan deskriptif yang bertujuan untuk mengkaji analisis manajemen penerapan dari himbauan vaksinasi Covid-19 dalam mengurangi angka positif kantor kesehatan Kabupaten Boyolali. Hasil dari penelitian ini yaitu penanganan Covid-19 dengan vaksinasi di cakupan wilayah Dinas Kesehatan Boyolali terbukti dapat mengurangi tingkat positif di Boyolali.

\section{Metode Penelitian}

Subyek penelitian (responden) dapat diartikan sebagai pihak-pihak yang dibutuhkan dalam penelitian untuk dijadikan sampel dimana subjek penelitian membahas karakteristik subjek dimana didalamnya terdapat penjelasan populasi, sampel penelitian dan tekhnik sampling (Aviandari et al., 2021). Penelitian ini dilakukan pada bulan september dimana, dalam penelitian ini subjek penelitian yang diambil adalah masyarakat dan pemerintah Kota Boyolali baik yang sudah melakukan vaksinasi maupun belum. Sampel yang digunakan adalah pemerintah, dimana dalam penelitian kualitatif sampel dituju kepada seseorang yang memberikan informasi atau sebagai narasumber sehingga sampel dalam penelitian ini adalah pemerintah Dalam penelitian ini metode yang kami gunakan metode studi pustaka dengan pendekatan kulaitatif ( $\mathrm{N}$, 2021). Dengan metode studi pustaka maka pengumpulan data dilakukan dengan mempelajari referensi-referensi seperti buku, artikel, browsing internet, dan literature review yang berkaitan dengan analisis sistem. Tahapan proses penelitian menggunakan metode ini yaitu dengan menghimpun data-data baik primer maupun sekunder dan juga mengklasifikasikan data berdasarkan formula penelitian (Darmalaksana et al., 2020). Kemudian selanjutnya pengolahan data atau dapat disebut pengutipan referensi untuk menjadi temuan penelitian, diabstraksikan untuk mendapkatkan informasi yang utuh dan diinterpretasikan sehingga dapat dijadikan bahan untuk menarik kesimpulan.

\section{Hasil dan Pembahasan}

Setelah tersedianya Pembahasan Vaksin Covid-19, Pemerintah menyalurkan ke 34 Provinsi di Indonesia dengan gratis (RI, 2021). Di Boyolali Tenaga Medis menerima 
jadwal Vaksinasi tahap pertama yang akan dilaksanakan pada minggu ke 3 tanggal 22 Januari 2021. Kepala Dinkes Boyolali dokter Ratri S. Survivalina (Senin, 4 Januari 2021) menyatakan bahwa proses distribusi Vaksin Covid-19 dilaksanakan pada minggu kedua, sedangkan pelaksanaan Vaksinasi dilakukan pada minggu ketiga tanggal 22 Januari 2021 (Gurning et al., 2021). Berdasarkan jumlah tenaga medis yang ada di Boyolali, terdapat 4.423 tenaga medis yang akan menerima Vaksinasi Covid-19 tahap pertama dengan faskes yang terlibat sejumlah 50 unit (Dewi \& Bustan, 2021). Kegiatan Vaksinasi Covid-19 lanjutan tahap pertama dilaksanakan pada tanggal 23 Februari 2021 sampai 28 Februari 2021 bagi seluruh tenaga kesehatan yang belum mendapatkan Vaksin. Kegiatan tersebut dimulai pada pukul 08.00 - 17.00 WIB (covid19.go.id, 2021). Pembukaan kegiatan vaksinasi diawali dengan adanya pidato dan pengarahan yang disampaikan oleh Kepala Dinas Kesehatan Kabupaten Boyolali, dilanjutkan dengan koordinasi bersama antara Kepala Dinas Kesehatan, Kepala Bidang Pengelolaan Pemberantasan Penyakit, Kepala Seksi Surveilans dan Imunisasi, dan Tim Vaksinator lainnya (Nasir et al., 2021). Alur berjalannya kegiatan Vaksinasi Covid-19 tersebut dimulai dengan pemberian nomor antrian kepada peserta yang hadir, kemudian semua peserta dilakukan pengecekkan suhu tubuh dan diminta untuk mencuci tangan terlebih dahulu sebelum menuju ruang tunggu. Kemudian setiap peserta vaksinasi menunggu di kursi tunggu hingga mendapat panggilan sesuai nomor urut. Setiap peserta secara berurutan sesuai nomor menuju ke Meja 1 (Meja Pendaftaran) untuk dilakukan pendataan peserta dengan menunjukkan KTP, lalu ke Meja 2 (Meja Screening) untuk dilakukan pengecekkan kesehatan dan juga cek tensi. Kemudian menuju ke Meja 3 (Meja Vaksinasi) untuk mendapatkan suntikan Vaksin Covid-19, dan terakhir menuju ke Meja 4 (Meja Pencatatan, Monitoring pasca vaksin, dan Pemberian Kartu) untuk melakukan monitoring setelah pemberian vaksin dan pencetakan kartu vaksinasi. Setelah semua meja sudah selesai, peserta vaksin menunggu selama 30 Menit untuk melihat apakah ada respon atau keluhan yg muncul setelah dilakukannya Vaksinasi. Jika sudah selesai semua peserta bisa untuk meninggalkan tempat dan menunggu informasi pemberian vaksinasi lanjutan Dosis ke 2 melalui media online untuk mengurangi kerumunan (Dinas Kesehatan kabupaten Boyolali, 2021).

Dinas Kesehatan Boyolali mengumumkan pelaksanaan Vaksinasi Covid-19 bagi lansia yang akan dilaksanakan pada tanggal 15 Maret 2021. Kategori peserta yang masuk dalam lansia adalah mereka yang memiliki usia lebih dari 60 tahun, pemberian Vaksin bagi Lansia di Boyolali dihadiri langsung oleh Bupati Boyolali, Bapak M.Said Hidayat didampingi oleh Kepala Dinas Kesehatan Boyolali, Ibu Ratri S.Lina. kehadiran Bupati Boyolali memiliki tujuan untuk memantau jalannya kegiatan Vaksinasi Covid-19 bagi lansia di Kabupaten Boyolali. Pelaksanaan kegiatan ini dilakukan pada pukul 08:00-16:00 WIB.

Alur pemberian Vaksinasi Covid-19 untuk lansia sama dengan alur vaksinasi Covid-19 kepada tenaga medis dimulai dengan pemberian nomor antrian kepada peserta 
yang hadir, kemudian semua peserta dilakukan pengecekkan suhu tubuh dan diminta untuk mencuci tangan terlebih dahulu sebelum menuju ruang tunggu. Kemudian setiap peserta vaksinasi menunggu di kursi tunggu hingga mendapat panggilan sesuai nomor urut. Setiap peserta secara berurutan sesuai nomor menuju ke Meja 1 (Meja Pendaftaran) untuk dilakukan pendataan peserta dengan menunjukkan KTP, lalu ke Meja 2 (Meja Screening) untuk dilakukan pengecekkan kesehatan dan juga cek tensi. Kemudian menuju ke Meja 3 (Meja Vaksinasi) untuk mendapatkan suntikan Vaksin Covid-19, dan terakhir menuju ke Meja 4 (Meja Pencatatan, Monitoring pasca vaksin, dan Pemberian Kartu) untuk melakukan monitoring setelah pemberian vaksin dan pencetakan kartu vaksinasi (Widayanti \& Kusumawati, 2021).

\section{Kesimpulan}

Program vaksinasi di Indonesia pertama kali dilakukan pada tanggal 13 Januari 2021 yang suntikan pertamanya diberikan kepada presiden Joko Widodo. Di Boyolali Tenaga Medis menerima jadwal Vaksinasi tahap pertama yang akan dilaksanakan pada minggu ke 3 tanggal 22 Januari 2021 dimana proses distribusi Vaksin Covid-19 dilaksanakan pada minggu kedua, sedangkan pelaksanaan Vaksinasi dilakukan pada minggu ketiga tanggal 22 Januari 2021. Dari penjelasan di atas dapat disimpulkan jika pelaksanaan vaksinasi di Boyolali sudah dapat berjalan dengan baik, dimana sudah dilaksanakan sesuai dengan aturan pemerintah yaitu vaksinasi dilakuakan dalam dua tahapan. Selain itu, prosedur pelayanan vaksinasi juga cukup transparan mulai dari antrian hingga dapat menerima vaksin. 


\section{BIBLIOGRAFI}

Aviandari, T., Pamungkasari, E. P., \& Murti, B. (2021). Management Analysis of the Implementation of Covid-19 Vaccination in Reducing Positivity Rate in Regency Health Office of Boyolali, Central Java. Journal of Health Policy and Management, 6 (3), 190-202. Google Scholar

Covid19.go.id. (2021). Lonjakan Kasus Dampak Abaikan Protokol Kesehatan. Https://Covid19.Go.Id. https://covid19.go.id/p/berita/lonjakan-kasus-dampakabaikan-protokol-kesehatan. Google Scholar

Darmalaksana, W., Hambali, R., Masrur, A., \& Muhlas, M. (2020). Analisis pembelajaran online masa wfh pandemic covid-19 sebagai tantangan pemimpin digital abad 21. Karya Tulis Ilmiah (KTI) Masa Work From Home (WFH) Covid19 UIN Sunan Gunung Djati Bandung, 1-12. Google Scholar

Dewi, A., \& Bustan, R. (2021). Sosialisasi Vaksinasi COVID-19 dan Protokol Kesehatan 7M Sebagai Upaya Pencegahan Penyebaran Virus COVID-19. Seminar Nasional Penelitian Dan Pengabdian Kepada Masyarakat (SNPPM-3), 197-209. Google Scholar

Dinas Kesehatan kabupaten Boyolali. (2021). Pelaksanaan Serbuan Vaksinasi Covid-19 Pedagang Pasar Tradisional Se-Kabupaten Boyolali. Dinkes Boyolali. https://dinkes.boyolali.go.id/82/pelaksanaan-serbuan-vaksinasi-covid-19pedagang-pasar-tradisional-sekabupaten-boyolali. Diakses tgl 2 Oktober 2021. Google Scholar

Gurning, F. P., Siagian, L. K., Wiranti, I., Devi, S., \& Atika, W. (2021). Kebijakan Pelaksanaan Vaksinasi Covid-19 Di Kota Medan Tahun 2020. Jurnal Kesehatan, 10 (1), 43-50. Google Scholar

N, K. (2021). Hari ini Vaksin Didistribusikan, Berikut Jadwal Tenaga Kesehatan Boyolali akan Divaksinasi. Www.Pikiran-Rakyat.Com. https://www.pikiranrakyat.com/nasional/amp/pr 011214335/hari-ini-vaksin-didistribusikan-berikutjadwal-tenaga-kesehatan-boyolali-akan-divaksinasi. Google Scholar

Nasir, N. M., Joyosemito, I. S., Boerman, B., \& Ismaniah, I. (2021). Kebijakan Vaksinasi COVID-19: Pendekatan Pemodelan Matematika Dinamis Pada Efektivitas Dan Dampak Vaksin Di Indonesia. Jurnal Pengabdian Kepada Masyarakat UBJ, 4 (2). Google Scholar

Organization, W. H. (2020). Coronavirus disease 2019 (COVID-19): situation report, 73. Google Scholar

Putri, R. S., Purwanto, A., Pramono, R., Asbari, M., Wijayanti, L. M., \& Hyun, C. C. (2020). Impact of the COVID-19 pandemic on online home learning: An 
explorative study of primary schools in Indonesia. International Journal of Advanced Science and Technology, 29 (5), 4809-4818. Google Scholar

RI, K. (2019). Keputusan menteri kesehatan republik indonesia nomor hk. 01.07/menkes/328/2020 tentang panduan pencegahan dan pengendalian., 2019 Keputusan Menteri Kesehatan Republik Indonesia Nomor Hk. 01.07. Menkes/413/2020 Tentang Pedoman Pencegahan Dan Pengendalian Coronavirus Disease, 2020. Google Scholar

RI, K. (2021). Pelaksanaan Vaksinasi COVID-19 di Indonesia Membutuhkan Waktu 15 Bulan Sehat Negeriku. Kemkes.Go.Id.

https://www.google.com/search?q=https+\%3A\%2F\%2Fsehatnegeriku+.kemkes.go .id\%2Fbaca\%2Frilis+media\%2F20210103\%2F2536122\%2Fpelaksanaan-

vaksinasi-covid-19-di-indonesia-+membutuhkan-wakt.+15-

bulan $\% 2 \mathrm{~F} \&$ oq $=$ https+\%3A\%2F\%2Fsehatnegeriku+.kemkes.go.id $\% 2 \mathrm{Fbaca} \% 2 \mathrm{Frili}$ s+media\%2F20210103\%2F2536122\%2Fpelaksanaan-vaksinasi-covid-19-diindonesia-\%09membutuhkan-wakt.+15bulan\%2F\&aqs=chrome..69i57.562j0j7\&sourceid=chrome\&ie=UTF-8. Google Scholar

Stuppia, L., Capogreco, M., Marzo, G., La Rovere, D., Antonucci, I., Gatta, V., Palka, G., Mortellaro, C., \& Tetè, S. (2011). Genetics of syndromic and nonsyndromic cleft lip and palate. Journal of Craniofacial Surgery, 22 (5), 1722-1726. Google Scholar

Tifa, I. (2021). Would you do anything differently? Work(Reading, Mass.). Google Scholar

Widayanti, L. P., \& Kusumawati, E. (2021). Hubungan persepsi tentang efektifitas vaksin dengan sikap kesediaan mengikuti vaksinasi Covid-19. HEARTY: Jurnal Kesehatan Masyarakat, 9 (2), 78-85. Google Scholar

\section{Copyright holder:}

Niken, PutriMia, Septiana, Reyhan, Argha, Putra (2021)

First publication right:

Jurnal Syntax Admiration

This article is licensed under:

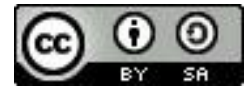

